Dept. of Food Hygiene,

Fac. Vet. Med., Alex. Univ., Egypt.

\title{
EFFECT OF YOGHURT PROCESSING AND ICE CREAM MANUFACTURE ON VIABILITY OF SOME FOODBORNE BACTERIA
}

(With 4 Figures)

\author{
By \\ A.A. AMER;A.S. AIAD* and M.A. ABD-ALLAH* \\ * Animal Health Research Institute (Alexandria branch), Egypt \\ (Received at 1/9/2010)
}

تأثير تصنيع الزبادي والأيس كريم على حيوية بعض البكتيريا الممرضة

عمرو عبد المؤمن عامر ، أحد صلاح اللدين عياد ، معد /حمد عبدالله

يعتبر الزبادي والأيس كريم من منتجات الألبان واسعة الانتشار لم ا تحتويه من عناصر غذائية

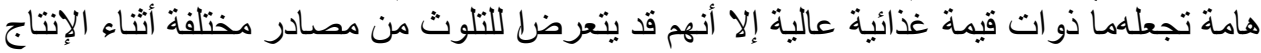

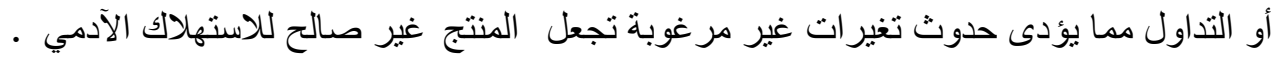

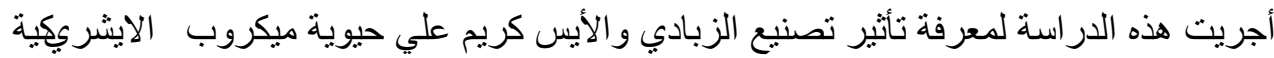
القولونية عترة O157:H7 المسيبة للالتهاب المعوي النازف وميكروب الئائ اليارسينيا انتيروكوليتيكا.

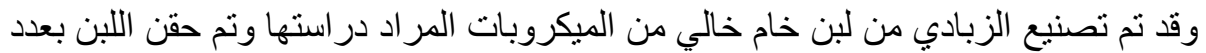

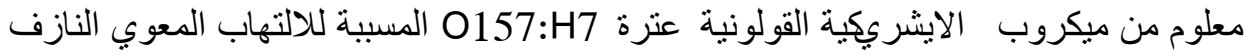
وميكروب اليارسينيا انتيروكوليتيكا وتم تخزينه عند درجة حرارة الثناجة 4 مْ وتم أخذ عينات

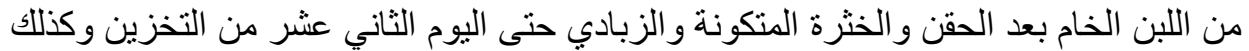

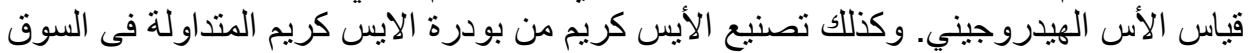

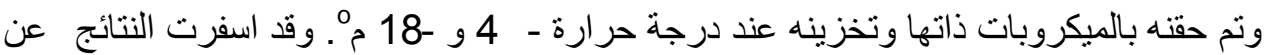
أن ميكروب الايشريكية القولونية عترة O157:H7 لها القدرة علي المقاومة في عينات الزبادي

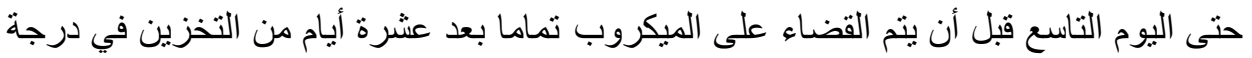

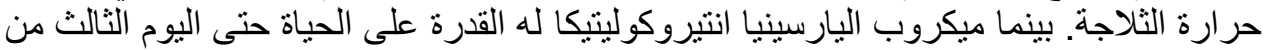

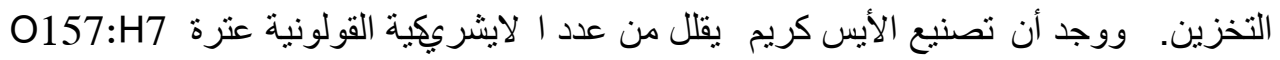

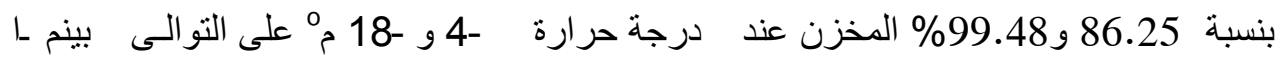
ميكروب اليارسينيا انتيروكوليتيكا قل بنسبة 99.47 و99.93\% المخزن عند درجة حرارة 4 و -18 م على التو الى ـ ـوقد تم مناقثة الأهمية الصحية لهذه الميكروبات والإحتياجات والمعيير الواجب تو افرها حتى ينم التحكم في مصادر التلوث. 


\section{SUMMARY}

Food borne bacterial gastrointestinal infections are important causes of morbidity and mortality worldwide. Despite of successful control programs in some developing countries, these infections continue to have major impacts on public health and economy. The present study was planned to spotlight on the effect of processing, as well as storage of yoghurt and ice cream on survival of Enterohemorrhagic E. coli O157: H7 and Yersinia enterocolitica. Yoghurt and ice cream that were manufactured in the laboratory inoculated with the organisms being tested. In case of yoghurt raw milk inoculated with Enterohemorrhagic E. coli $\mathrm{O} 157: \mathrm{H} 7$ and Yersinia enterocolitica at density of $5.13 \times 10^{4}$ and $8.1 \times 10^{4}$ (cfu/ml), respectively and stored at $4^{\circ} \mathrm{C}$. Samples of milk, curd and finished product were examined up to $12^{\text {th }}$ day of storage for growth of tested organisms and $\mathrm{pH}$ value. While, ice cream samples inoculated with Enterohemorrhagic E. coli and Yersinia enterocolitica at density of $1.55 \times 10^{5}$ and $8.2 \times 10^{5}(\mathrm{cfu} / \mathrm{ml})$, respectively and stored at $\left(-4^{\circ} \mathrm{C}\right)$ and $\left(-18^{\circ} \mathrm{C}\right)$. The effect of freezing on growth and survival of both organisms examined daily up to $35^{\text {th }}$ day of storage. Enterohemorrhagic E. coli and Yersinia enterocolitica could survive in yoghurt before completely reduced at the $10^{\text {th }}$ and $4^{\text {th }}$ day of storage, respectively. The results of ice cream obtained by the end of storage indicated that Enterohemorrhagic E.coli and Yersinia enterocolitica count reduced at $-4^{\circ} \mathrm{C}$ by 86.25 and $99.4 \%$ respectively. Also, at $-18^{\circ} \mathrm{C}$ by 99.4 and $99.9 \%$, respectively. So, the concerned health authorities should impose regulations and bacteriological standards on the manufacturers also, tacking an active part by monitoring the health of dairy used to ensure the best possible protection for the consumer. In Addition to the enforcement of GMP and HACCP system inside dairy plants is of critical.

Key words: Enterohemorrhagic E. coli O157:H7, Yersinia enterocolitica, yoghurt, ice cream

\section{INTRODUCTION}

Milk is a highly perishable commodity and difficult to handle, especially in a country with high ambient summer temperature. Enterohemorrhagic E. coli O157:H7 (EHEC) constitutes a significance risk to human health worldwide and the infection is associated with consumption of food of bovine origin (Philips et al., 2000). The spectrum of clinical illness ranges from mild diarrhea, through bloody diarrhea and hemolytic uraemic syndrome (HUS), thrombotic thrombocytopenic 
purpura (TTP) and renal failure in children (Fitzpatrick et al., 1991, Locking et al., 2001, Razzaq, 2006). Verocytotoxin-producing E. coli O157:H7 (VTEC) has been identified as a possible contaminant of raw milk (Bryan, 1983). The gastro-intestinal tracts of ruminants, especially cattle, and humans are likely to present the main reservoirs of E. coli O157:H7 (Duffy et al., 2001). In the USA raw milk was responsible for 5\% of the E. coli O157:H7 outbreaks from 1982 to 1995 (Wachsmuth et al., 1997). Later on E. coli $\mathrm{O} 157: \mathrm{H} 7$ constitutes $33 \%$ of milk borne general outbreaks of infectious intestinal diseases as a result of unpasteurized milk consumption (Gillespie et al., 2003).

Yersinia enterocolitica is a zoonotic, Gram-negative bacterium capable of causing severe gastrointestinal infection (Varnam and Evans, 1991, Butler, 1998). It produces a heat stable enterotoxin that is associated with food poisoning strains in man (Bielecki, 2003). The frequent association of this organism to raw milk and its ability to grow in milk over a long period of time under freezing, thawing and constant freezing condition would facilitate its survival in the environment and its transmission via milk (Larkin et al., 1991). In England and Wales, laboratory reports mostly sporadic cases increased from 45 in 1980 to more than 590 in 1989 (Adams and Moss, 2000). The importance of Yersinia enterocolitica as a cause of foodborne illness especially in developing countries may be due to the unhygienic conditions under which small individual producer milked the animals, long distance between the production and market areas, poor transportation, and insufficient or nonavailability of milk cooling, and chilling system.

The objective of this study was planned to spotlight on the effect of yoghurt processing, and ice cream manufacture and storage period on the survival of Enterohemorrhagic E. coli O157:H7and Yersinia enterocolitica.

\section{MATERIALS and METHOD}

Test organisms: Escherichia coli O157: H7 strain was kindly obtained from Department of Microbiology, Faculty of Veterinary Medicine, Giza, Egypt. The inoculum was prepared by streaking E. coli O157: H7 from refrigerated stock agar slant culture into Tellurite Cefixime SorbitolMacConkey agar plates (TCSMAC). Plates were incubated at $37^{\circ} \mathrm{C}$ for 24 hrs. One separate colony was then picked and inoculated into sterile modified tryptic soy broth (TSB). Broth tubes were incubated at $37^{\circ} \mathrm{C}$ for $24 \mathrm{hrs}$. After two successive transfers and incubation, the culture was maintained in sterile $0.1 \%$ peptone water which served as the working culture. 
Yersinia enterocolitica strain was kindly obtained from Department of Microbiology, Animal Health Research Institute, Dokki, Giza, Egypt. The inoculum was grown in trypticase soy broth at $22{ }^{\circ} \mathrm{C}$ for $18 \mathrm{hrs}$. After two successive transfers and incubation, the culture was maintained in sterile $0.1 \%$ peptone water which served as the working culture.

Yoghurt manufacturing: Raw milk was taken from the experimental station of the Department of Animal Production, Faculty of agriculture, Alexandria University to be used for yoghurt manufacture at the laboratory. The milk was dispatched to the laboratory in clean, dry and sterile flasks with a minimum of delay. Yoghurt cultures (IST from 2\% NIZO) were obtained from Department of Milk and Dairy Technology, Faculty of Agriculture, Alexandria University. The cultures were thawed at room temperature $\left(20{ }^{\circ} \mathrm{C}\right)$. Two consecutive transfers in sterile skim milk were made and incubated at $37{ }^{\circ} \mathrm{C}$ for 24 hours prior to use in yoghurt manufacture. Raw milk was heated to $90{ }^{\circ} \mathrm{C}$ for 30 minutes and then cooled to about $40{ }^{\circ} \mathrm{C}$. The starter cultures $(2 \%)$ of Lactobacillus bulgaricus and Streptococcus thermophilus in a ratio of 1: 1 were added to milk and thoroughly mixed. The prepared cultured milk was divided into two parts. The first one was inoculated with E. coli $\mathrm{O} 157: \mathrm{H} 7$ to provide the desired number of pathogen $5.13 \times 10^{4}(\mathrm{cfu} / \mathrm{ml}$ ) and to the second part Yesinia enterocolitica was added to provide the desired number of pathogen $8.1 \times 10^{4}(\mathrm{cfu} / \mathrm{ml})$. The samples were incubated at $45^{\circ} \mathrm{C}$ to be coagulated. Samples of milk, curd and finished product stored at refrigerator temperature $\left(4 \pm 1^{\circ} \mathrm{C}\right)$ were examined daily up to 10 days of storage for growth of E. coli $\mathrm{O} 157: \mathrm{H} 7$ and Yersinia enterocolitica.

Ice cream manufacturing: Packets of ice cream powder were purchased from various supermarkets in Alexandria Governorate and dispatched to the laboratory. Two random samples were prepared according to the manufacturer (Egyptian Dairy \& Food Company). One was inoculated with prepared culture of E. coli $\mathrm{O} 157: \mathrm{H} 7$ to obtain a count of $1.55 \times 10^{6}$ (cfu / ml). While, the second was inoculated with prepared culture of Yersinia enterocolitica to obtain a count of $8.2 \times 10^{6}$ (cfu / ml). Each sample was divided into two portions, one was kept at $-4{ }^{\circ} \mathrm{C}$ and the other was stored at deep freezing $\left(-18^{\circ} \mathrm{C}\right)$. The effect of freezing on growth and survival of E. coli $\mathrm{O} 157: \mathrm{H} 7$ or Yesinia enterocolitica was determined daily up to 35 day of storage.

Enumeration of tested organisms: It was achieved by direct surface plating technique using decimal dilutions of prepared samples according to the method of APHA (1992) in which $0.1 \mathrm{ml}$ of each serial dilution was surface plated into the selective medium. In case of E. coli O157: H7 Tellurite Cefixime Sorbitol-MacConkey (TCSMAC) agar plates (Oxoid, 
1998) were used and incubated at $37^{\circ} \mathrm{C}$ for 24 hrs. Typical E. coli O157: $\mathrm{H} 7$ colony is neutral, gray with a smoky center and 1-2 $\mathrm{mm}$ in diameter was counted. While, Cefsulodin-Igrasan-Novobiocin (CIN) (Oxoid, 1998) used for Yersinia enterocolitica. Plates incubated at $22{ }^{\circ} \mathrm{C}$ for $48 \mathrm{hr}$. Typical colony of organism has deep red center with a rather sharp border and translucent outer zone was counted.

\section{RESULTS and DISCUSSION}

\section{1- Effect of yoghurt processing and storage on viability of $E$. coli 0157:H7}

Figure 1 revealed the population of $E$. coli $\mathrm{O} 157: \mathrm{H} 7$ changed with different rates during the manufacturing and refrigerated storage of yoghurt. From the initial milk inoculation until clotting (Zero time), the inoculum levels of $E$. coli $\mathrm{O} 157: \mathrm{H} 7$ increased from $5.13 \times 10^{4} \pm 3.21 \times 10^{3}$ to $2.13 \times 10^{5} \pm 5.0 \times 10^{4}(\mathrm{cfu} / \mathrm{ml})$. This means that, bacterial cell number increased during yoghurt manufacturing by nearly 10 -fold (1 log cycle) as a result of physical entrapment in the curd. In addition to this, growth of $E$. coli $\mathrm{O} 157: \mathrm{H} 7$ may also occur during yoghurt manufacturing as the temperature used for yoghurt incubation is approaching the optimum growth temperature for that organism. Since it is well known that different strains of $E$. coli $\mathrm{O} 157$ exhibit slightly different growth temperature optima from 38.5 to $42.5^{\circ} \mathrm{C}$ (Gonthier et al., 2001).

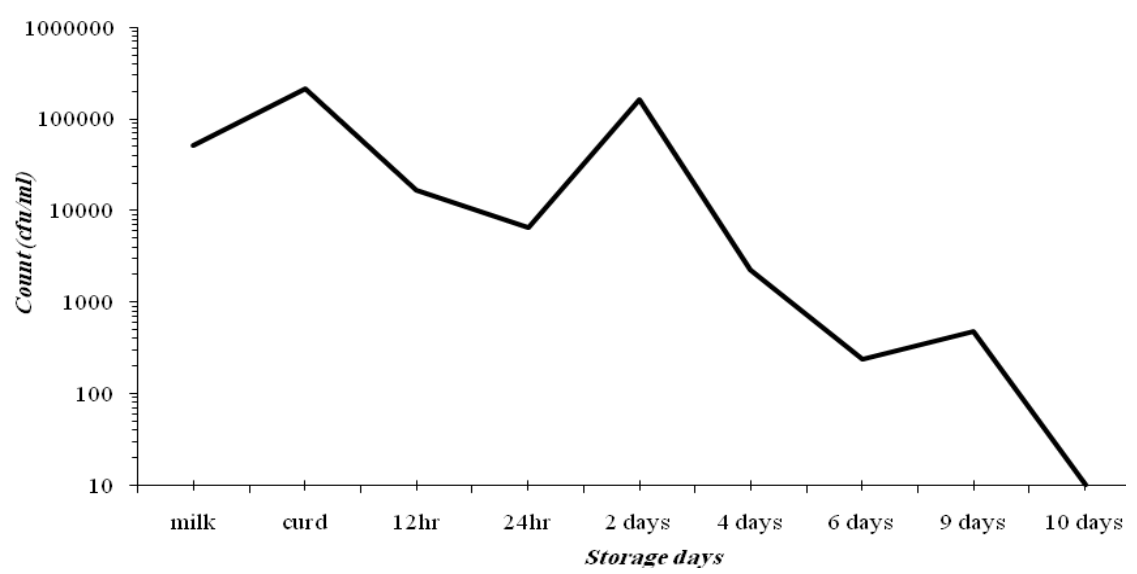

Fig. 1: Survival of Enterohemorrahgic E.coli in yoghurt during processing and storage 
After two days of refrigerated storage, E. coli O157:H7 count begins to decrease significantly to $1.65 \times 10^{5} \pm 3.50 \times 10^{4}(\mathrm{cfu} / \mathrm{ml})$ which accompanies the fall down of yoghurt $\mathrm{pH}$ to 4.5. The decline of viable population of E. coli O157: $\mathrm{H} 7$ after $48 \mathrm{hrs}$ of fermentation may be partly attributed to the production of bacteriocins, hydrogen peroxide and ethanol by starter cultures (Frank and Marth, 1988). Comparatively higher reduction rate of E. coli $\mathrm{O} 157: \mathrm{H} 7$ is recorded just after formation of the curd by Dineen et al. (1998). Such results differences could be attributed to using of different initial inoculum sizes upon processing of yoghurt and/or variability in the virulence among the tested strains (Oksuz et al., 2004). While, the number of $E$. coli $\mathrm{O} 157: \mathrm{H} 7$ declines continuously during refrigerated storage of yoghurt, significant numbers may still exist in the yoghurt after 9 days $4.80 \times 10^{2} \pm 2.50 \times 10(\mathrm{cfu} / \mathrm{ml})$. This is of great concern considering that expiry date of yoghurt is typically set to be after 15 days of manufacturing. These results also indicate that yoghurt made from milk contaminated with E. coli $\mathrm{O} 157: \mathrm{H} 7$ at level of $5.13 \times 10^{4} \pm 3.21 \times 10^{3}$ (cfu/ml) is likely to contain the bacterium at levels that are known to cause illness by the time it reaches the consumer. This of concern to both yoghurt manufacturers and consumers because of the low infectious dose associated with $E$. coli O157:H7 infections (Doyle et al., 1997). The ability of E. coli O157:H7 to induce an Adaptive Tolerance Response (ATR) when exposed to mild acid conditions confers a higher resistance on subsequent exposure to strong acid conditions (Doyle et al., 1997, Jordan et al., 1999). The induction of an ATR by mild acid conditions in the yoghurt may promote greater resistance to acid during passage through the stomach, thereby low ingested number of E. coli O157:H7 can cause infection. Moreover, it has been shown that casein of dairy products protects pathogens from acidic stress (Rubin, 1985). This may be another factor that enables E. coli O157:H7 to survive in the acidic conditions of yoghurt. Since milk fermentation produce anaerobic conditions within the fermented dairy products, it is thought that anaerobic growth of E. coli $\mathrm{O} 157: \mathrm{H} 7$ in an acidic medium, like yoghurt, results in the development of acid tolerance (Cheng and Kaspar, 1998). The development of similar acid tolerance effects would be expected to also occur in this study. It seems that the presence of E. coli O157: $\mathrm{H} 7$ and its survival at both low temperature and $\mathrm{pH}$ in this study confirmed the implication of acidic food in some recent outbreaks due to EHEC infection (Sharpe et al., 1995).

2- Effect of yoghurt processing and storage on viability of Yersinia enterocolitica:

Abd El-Hady (1993) reported that Yersinia enterocolitica could survive for 7 days in yoghurt. In contrast our results revealed that Yersinia 
enterocolitica slightly decreased in counts from $8.1 \times 10^{4} \pm 5.0 \times 10^{2}$ (cfu/ml) to $4.4 \times 10^{3} \pm 1.5 \times 10^{2}(\mathrm{cfu} / \mathrm{ml})$ this may be due to the effect of the processing as well as the decrease of $\mathrm{pH}$ value from 6.4 to 4.7. Yersinia enterocolitica remained viable for 3 days and during the same period $\mathrm{pH}$ reduced to 4.2 (Figure 2). Similarly, Halawa (1995) studies the effect of yoghurt processing and cold storage temperature $\left(4^{\circ} \mathrm{C}\right)$ on survival of Yersinia enterocolitica (ATCC 27729) and his results revealed a reduction in organism count due to increase the acidity of the stored product.

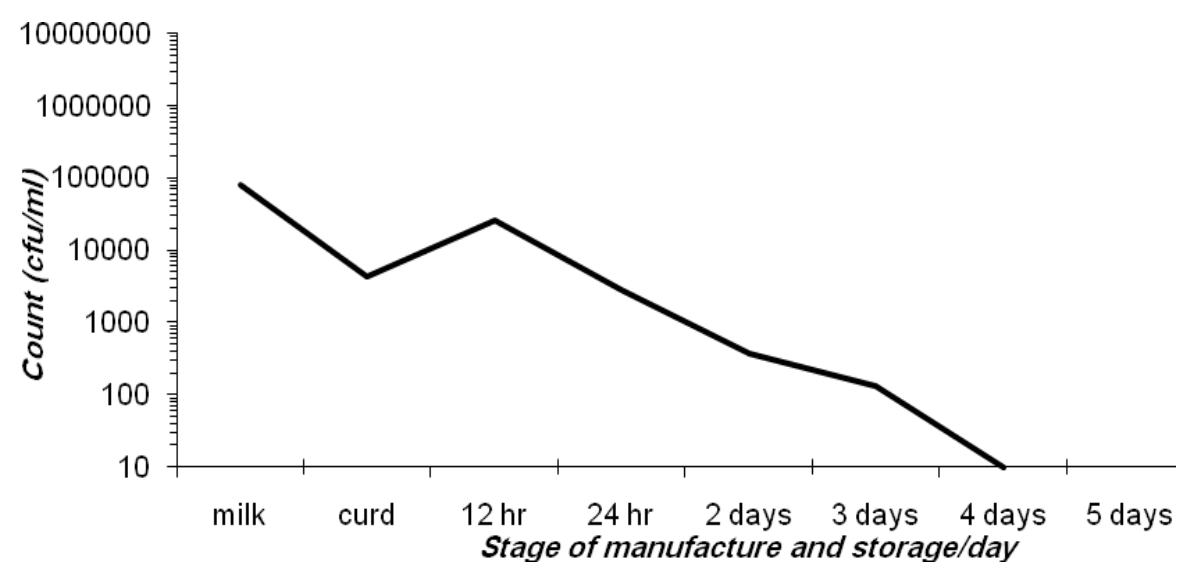

Fig. 2: Effect of yoghurt processing and storage on survival of Yersinia enterocolitica

In present study the reduction in Yersinia enterocolitica count also, may be attributed to the initial size of the inoculum and storage temperature. Canganella et al. (1998) investigated the survival of Yersinia enterocolitica in fruit yoghurt after inoculation at two different levels $\left(10^{2}-10^{3} \mathrm{cfu} / \mathrm{ml}\right.$ and $\left.10^{4}-10^{6} \mathrm{cfu} / \mathrm{ml}\right)$ during storage at $4{ }^{\circ} \mathrm{C}$. The study indicated non significant change in the organism count during three days of storage and complete reduction of it occurred after two weeks of product storage except when the size of the initial inoculum was larger than $10^{5}$ cfulml in this case viable cells of the pathogen were still recovered after 17 days of storage in addition, survival of Yersinia enterocolitica was better during storage at $4{ }^{\circ} \mathrm{C}$ than $8{ }^{\circ} \mathrm{C}$.

\section{3- Effect of freezing on viability of $E$. coli $0157: \mathrm{H} 7$ in ice cream}

Freezing has been established as an excellent method of preserving quality in foods. So, extensive quantities of foods are now frozen 
worldwide. Freezing preserves the taste, texture and nutritional value of foods better than any other method (Marilyn and Yen-con, 1997).

The organisms can survive well at $-20^{\circ} \mathrm{C}$ and at $-18^{\circ} \mathrm{C}$ for up to 9 months (Doyle and Schoeni, 1984). Although, ice cream has not yet been directly implicated in outbreaks of E. coli O157:H7 (Rothwell, 1990). Figure (3) showed the growth pattern of E. coli O157:H7 during frozen storage of ice cream at -4 and $-18{ }^{\circ} \mathrm{C}$. The initial population $1.55 \times 10^{5} \pm$ $3.15 \times 10^{4}(\mathrm{cfu} / \mathrm{ml})$ decreased gradually to reach $2.13 \times 10^{4} \pm 8.21 \times 10^{3}$ and $7.94 \times 10^{3} \pm 1.32 \times 10^{2}(\mathrm{cfu} / \mathrm{ml})$ with reduction percent of 86.25 and $99.48 \%$, respectively by the end of $35^{\text {th }}$ day of storage. Our results agree with previous studies (Susan and Cameron, 1994 and Abou-Zeid et al., 2001) that E. coli O157:H7 proved capability to survive very well in refrigerated dairy products. Disagreement stated by Wang et al. (1997) who noted that $E$. coli $\mathrm{O} 157: \mathrm{H} 7$ did not grow at $5^{\circ} \mathrm{C}$ in milk and its population decreased.

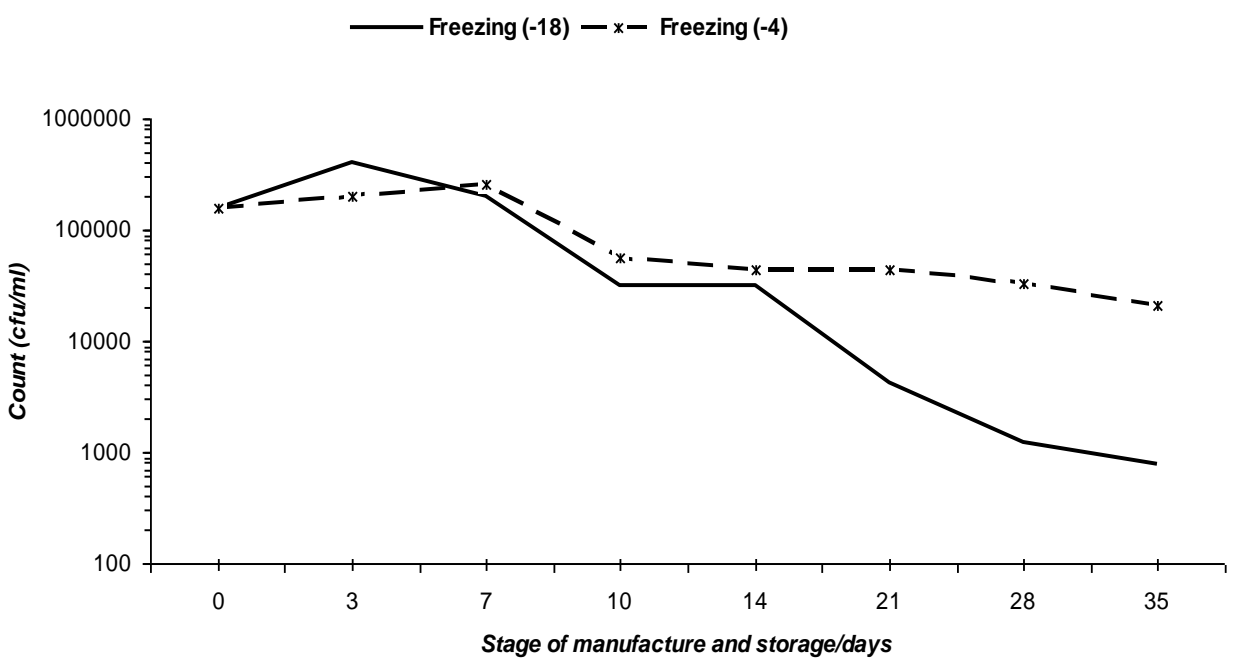

Fig. 3: Effect of freezing on survival of Enterohemorrahgic E. coli in ice cream stored at freezing temperature at -4 and $-18{ }^{\circ} \mathrm{C}$

\section{4- Effect of freezing on viability of Yersinia enterocolitica in ice cream}

Yersinia enterocolitica could withstand freezing and surviving for long periods in frozen food, even after repeated freezing and thawing (Toora, 1992). Figure 4 Yersinia enterocolitica counts in ice cream samples that there was a gradual reduction in counts from $8.2 \times 10^{5} \pm 5.0 \times 10^{4}$ 
$(\mathrm{cfu} / \mathrm{ml})$ to $4.3 \times 10^{3} \pm 5.0 \times 10^{2}(\mathrm{cfu} / \mathrm{ml})$ by the end of the $35^{\text {th }}$ day of storage at freezing temperature $\left(-4{ }^{\circ} \mathrm{C}\right)$ with reduction percent of $99.4 \%$. While in case of ice cream samples stored at (-18) reached a count of $5.0 \mathrm{x}$ $10^{2} \pm 1.2 \times 10^{2}(\mathrm{cfu} / \mathrm{ml})$ by the end of the $35^{\text {th }}$ day of storage with a reduction percent of $99.9 \%$. These result substantiated by Annamalai and Venkitanarayanam (2005) who reported that Yersinia enterocolitica is a foodborne pathogens that had been implicated in outbreaks of foodborne illness involving cold stored foods.

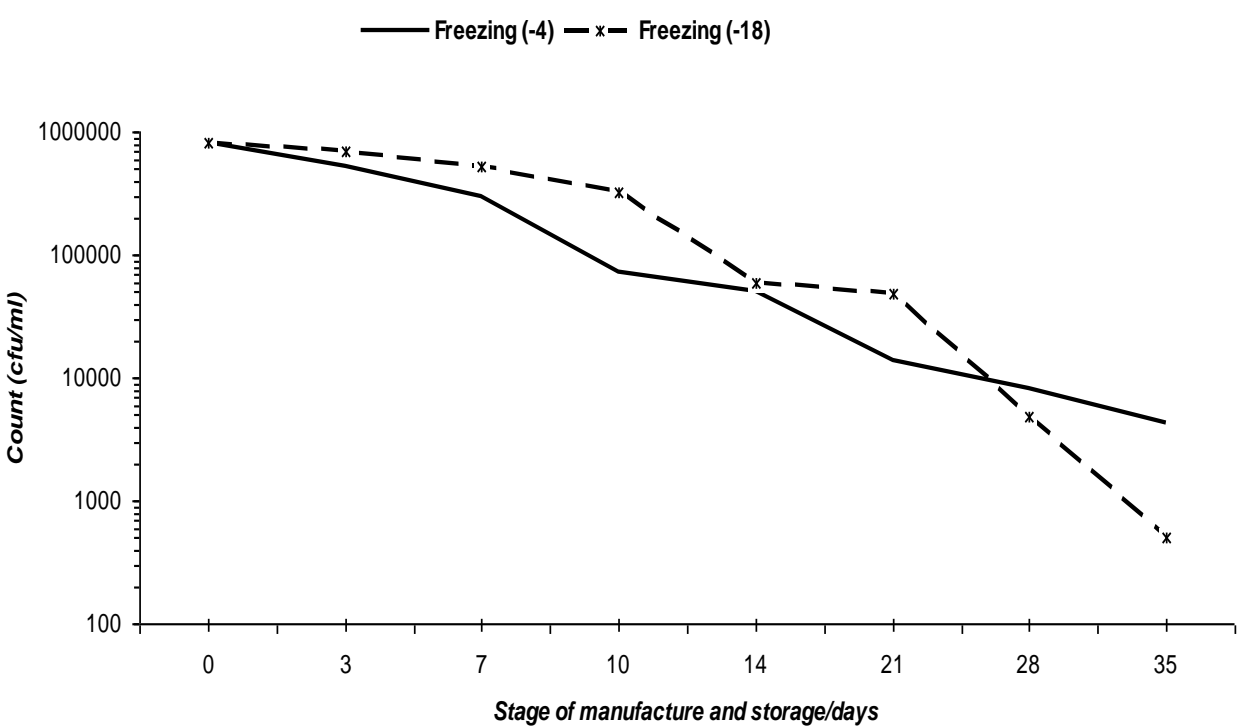

Fig. 4: Effect of freezing temperature on survival of Yersinia enterocolitica in ice cream

From the above findings, we can concluded that the storage temperature, $\mathrm{pH}$ and the size of inoculum may have a great influence upon the growth of Yersinia enterocolitica and E. coli O157:H7 during manufacturing of yoghurt and ice cream. So, the concerned health authorities should impose regulations and bacteriological standards on the manufacturers also, tacking an active part by monitoring the health of dairy used to ensure the best possible protection for the consumer. In addition, the enforcement of GMP and HACCP system inside dairy plants is of critical. 


\section{REFERENCES}

Abd El-Hady, H.M. (1993): Studies on Campylobacter jejuni and Yersinia enterocolitica as food poisoning organisms in milk and some dairy products. Ph.D. Thesis, Fac. Vet. Med., Cairo Univ.

Abou-Zeid, A.M.; Abd-El Hady, H.M. and Halawa, M.A. (2001): Prevalence and survival of Listeria monocytogenes and Escherichia coli O157: H7 in ice-cream. Cong. of Food Hygiene and Human Health.6-8 February 2001 Dept. of Food Hygiene, Fac. Vet. Med., Assiut, Egypt.

Adams, M.S. and Moss, M.O. (2000): Food Microbiology $2^{\text {nd }}$ Ed. Royal Society of Chemistry. Thomas Graham House, Science Park, Milton Road Cambridge CB40WF, UK.

Annamalai, T. and Venkitanarayanan, K. (2005): Expression of major cold shock proteins and genes by Yersinia enterocolitica in synthetic medium and foods. J. Food Prot., 68(11): 2454-2458.

APHA, American Public Health Association (1992): Compendium of Methods for the Microbiological Examination of Foods. $3^{\text {rd }}$ Ed., Washington, DC, 20005.

Bielecki, J. (2003): Emerging food pathogens and bacterial toxins. Acta Microbiol. Pol., 52, Suppl., 17-22.

Bryan, F. (1983): Epidemiology of milk-borne diseases. J. Food Prot., 46: 637-649.

Butler, T. (1998): Yersinosis and plaque. In: Zoonoses - Biology, Clinical Practice and Public Health Control. Palmer, S.R.; Soulsby, L. and Simpson, D.I.H. (Eds.). Oxford, 281-293.

Canganella, F.; Ovidi, M.; Paganini, S.; Vettraino, A.M.; Bevilacqua, I. and Trovatelli, I.D. (1998): Survival of undesirable microorganisms in fruit yoghurts during storage at different temperatures. Food Microbiol. 15: 71-77.

Cheng, C.M. and Kaspar, C.W. (1998): Growth and processing conditions affecting acid tolerance in Escherichia coli O157: H7. Food Microbiol. 15: 157-166.

Dineen, S.S.; Takeuchi, K.; Soudah, J.E. and Boor, K.J. (1998): Persistence of Escherichia coli O157: H7 in dairy fermentation systems. J. Food Prot., 61: 1602-1608.

Doyle, M.P. and Schoeni, J.L. (1984): Survival and growth characteristics of Escherichia coli associated with hemorrhagic colitis. Appl. Environ. Microbiol. 48: 855-856. 
Doyle, M.P.; Zhao, T.; Meng, J. and Zhao, S. (1997): Escherichia coli O157: H7. In: Food Microbiology Fundamental and Frontiers. Doyle, M.P.; Beuchat, L.R. and Montville, T.J. eds. Am. Soc. Microbiol., Washington DC.

Duffy, G.; Garvey, P.; Wasteson, Y.; Coia, J.E. and McDowell, D.A. (2001): Epidemiology of Verocytotoxigenic E. coli. A technical booklet produced for an EU Concerted Action (CT98-3935). ISBN 1841702064.

Fitzpatrick, M.; Shah, V. and Dillon, M. (1991): Long term outcome of childhood haemolytic uraemic syndrome. Britain Med. J. 303: 489-492.

Frank, J.F. and Marth, E.H. (1988): Fermentation. In fundamentals of dairy chemistry. (Eds) N.P. Wong, R.; Keeney, M. and Marth, E.H. Eds. Pp. 655-738. New York, van Nostrand Reinhold. Appl. Environ. Microbiol. 70 (6): 3500-3505.

Gillespie, I.A.; Adak, G.K.; O'Brien, S.J. and Bollton, F.T. (2003): Milk borne general outbreaks of infectious intestinal disease, England and Wales, 1992-2000. Epidemiol. Infect. 130(3): 461-468.

Gonthier, A.; Guerin-Faublee, V.; Tilly, B. and Delignette-Muller, M.L. (2001): Optimal temperature of O157 and non-O157 Escherichia coli strains. J. lett. Appl. Microbiol., 33: 352-356.

Halawa, M.A. (1995): Survival of Listeria monocytogenes and Yersinia enterocolitica in yoghurt. Alex. J. Vet. Sci., 11(1): 107-110.

Jordan, K.N.; Oxford, L. and Obryne, C.P. (1999): Survival of low pH stress by Escherichia coli O157:H7: a correlation between the alteration in cell envelope and increased acid tolerance. Appl. Environ. Microbiol. 65: 3048-3055.

Larkin, L.L.; Vasavada, P.C. and Marth, A.H. (1991): Incidence of Yersinia enterocolitica in raw milk as related to its quality. Milchwissenschaft, 46(8): 500-502.

Locking, M.; Brien, S. and Reilly, E. (2001): Risk Factors for sporadic cases of Escherichia coli O157 infection: the importance of contact with animal excreta. Epidemiol. Infect. 127: 215-220.

Marilyn, C.E. and Yen-Con, H. (1997): Quality in frozen food. Chapman \& Hall, Dept. BC, 115 Fifth Avenue, New York, NY 10003.

Oksuz, O.; Arici, M.; Kurultay, S. and Gumus, T. (2004): Incidence of Escherichia coli $\mathrm{O} 157$ in raw milk and white pickled cheese manufactured from raw milk in Turkey. J. Food Control, 15: 453-456.

Oxoid (1998): The Oxoid Manual. Culture Media, Ingredients and Other Laboratory Services. $8^{\text {th }}$ Ed., Published by Oxoid Limited, UK 
Philips, A.; NavaBpour, S. and Hicks, S. (2000): Enterohaemorrhagic Escherichia coli O157:H7 target Peyer's patches in humans and cause attaching / effacing lesions in both human and bovine intestine. Gut, 47(3): 377-381.

Razzaq, S. (2006): Hemolytic uremic syndrome: an emerging health risk. Am. Fam. Physician. 74(6):991-6.

Rothwell, J. (1990): Microbiology of ice cream and related products. In Dairy Microbiology. $2^{\text {nd }}$ ed. Vol. 2. pp. 1-39 (Ed. R.K. Robinson) London. El Seveir Appl. Sci.

Rubin, H.E. (1985): Protective effect of casein toward S. typhimurium in acid milk. J. Appl. Bacteriol., 58: 251-255.

Sharpe, J.C.M.; Reilly, W.J.; Coia, J.E.; Currow, J. and Synge, B.A. (1995): Escherichia coli O157 infection in Scotland and epidemiological overview, 1984-1994. PHLS, Microbiol. Dig., 12: $134-140$.

Susan, E.D. and Cameron, R.H. (1994): Relevance of Escherichia coli O157: H7 to the dairy industry. Dairy Food and Environmental Sanitation, 14 (11) 656-660.

Toora, S. (1992): Effect of high temperature, short time pasteurization, freezing and thawing and constant freezing on the survival of Yersinia enterocolitica in milk. J. Food Prot., 55(10): 803-805.

Varnam, A.H. and Evans, M.G. (1991): Foodborne pathogens. An illustrated Textbook. Wolfe Publishing Ltd, New York. pp 129-155.

Wachsmuth, I.K.; Sparling, P.H.; Barrett, T.J. and Potter, M.E. (1997): Enterohemorrhagic Escherichia coli in the United States. FEMS, Immunol. Med. Microbiol., 18: 233-239.

Wang, G.; Zhao, T. and Doyle, M.P. (1997): Survival and growth of Escherichia coli O157: H7 in unpasteurized milk and pasteurized milk. J. Food Prot. 60: 610-61. 